\title{
KONDISI PRASARANA DASAR KAWASAN PERMUKIMAN SUNGAI REMU KOTA SORONG
}

\author{
NurHidayah Annas ${ }^{1)}$, SitiMarohatus Hidayatun ${ }^{2)}$ \\ ${ }^{1), 2)}$ Program Studi Tekik Sipil Universitas Muhammadiyah Sorong \\ Jl. Pendidikan No. 27 Kota Sorong \\ Email : nurhidayahannassipil@gmail.com
}

\begin{abstract}
Abstrak
Kota Sorong adalah sebuah Kota di Provisi Papua Barat, Indonesia. Kota ini dikenal dengan sebutan Kota Minyak, dimana Nederlands Nieuw-Guinea Petroleum Maatschappij (NNGPM) mulai melakukan aktivitas pengeboran minyak bumi di Sorong sejak tahun 1935. Sorong adalah kota terbesar di Provinsi Papua Barat serta Kota terbesar kedua di Papua Indonesia, setelah Kota Jayapura. Kepadatan penduduk adalah perbandingan jumlah penduduk dengan luas lahan. Secara umum, tingkat kepadatan penduduk adalah perbandingan banyaknya jumlah penduduk dengan luas daerah berdasarkan satuan luas tertentu. Badan Pusat Statistik mencatat pertumbuhan jiwa pada 2016 sebanyak 121.439 pria dan 111.394 perempuan. Penduduk Kota Sorong Didominasi oleh pendatang mencapai $70 \%$ sementara penduduk asli Papua berkisar $30 \%$. Kepadatan penduduk banyak terjadi didaerah kawan kumuh. Kawasan kumuh adalah sebuah kawasan dengan tingkat populasi tinggi disebuah Kota yang umumnya dihuni oleh rakyat miskin. Kawasan kumuh dapat ditemui diberbagai Kota besar di Dunia. Tujuan pembuatan artikel ini adalah untuk mengetahui kondisi prasarana dasar kawasan permukiman sungai remu Kota Sorong seperti jalan, air bersih, drainase, persampahan, dan air limbah. Kondisijalan yang ada cukup memenuhi hanya jalannya sudah mengalami kerusakan ringan. Air bersih yang ada kurang memenuhi karena sebagian besar menggunakan air dari PDAM dan air dari PDAM mengalir seminggu 2 kali dengan kualitas yang buruk. Drainase yang ada kurang memenuhi karena kondisi drainase perumahan terlalu kecil yang membuat air tergenang karena elevasi yang kurang tepat sehingga menjadi sarang nyamuk dan sebagian drainase terputus. Persampahan kurang memenuhi karena TPS terlalu jauh dari permukiman dan kontener yang disiapkan terlalu sedikit. Air Limbah kurang memenuhi karena limbah rumah tangga di alirkan kesungai dan membuat air sungai tercemar hingga tidak ramah lingkungan.
\end{abstract}

Kata Kunci : Permukiman, Sungai Remu, Kota Sorong, 


\section{PENDAHULUAN}

Kota Sorong adalah sebuah Kota di Provisi Papua Barat, Indonesia. Kota ini dikenal dengan sebutan Kota Minyak, dimana Nederlands Nieuw-Guinea Petroleum Maatschappij (NNGPM) mulai melakukan aktivitas pengeboran minyak bumi di Sorong sejak tahun 1935. Sorong adalah kota terbesar di Provinsi Papua Barat serta Kota terbesar kedua di Papua Indonesia, setelah Kota Jayapura.

Kepadatan penduduk adalah perbandingan jumlah penduduk dengan luas lahan. Secara umum, tingkat kepadatan penduduk adalah perbandingan banyaknya jumlah penduduk dengan luas daerah berdasarkan satuan luas tertentu. Badan Pusat Statistik mencatat pertumbuhan jiwa pada 2016 sebanyak 121.439 pria dan 111.394 perempuan. Penduduk Kota Sorong Didominasi oleh pendatang mencapai $70 \%$ sementara penduduk asli Papua berkisar 30\%. Kepadatan penduduk banyak terjadi didaerah kawan kumuh. Kawasan kumuh adalah sebuah kawasan dengan tingkat populasi tinggi disebuah Kota yang umumnya dihuni oleh rakyat miskin. Kawasan kumuh dapat ditemui diberbagai Kota besar di Dunia.

Tujuan pembuatan artikel ini adalah untuk mengetahui kondisi prasarana dasar kawasan permukiman sungai remu Kota Sorong seperti jalan, air bersih, drainase, persampahan, dan air limbah.

\section{METODOLOGI}

Lokasi Studi

Jl. Sungai Remu Malaingkedi, RW 05 / RT 01, kelurahan Remu Selatan, kecamatan Sorong Manoi, Kota Sorong, Papua Barat.

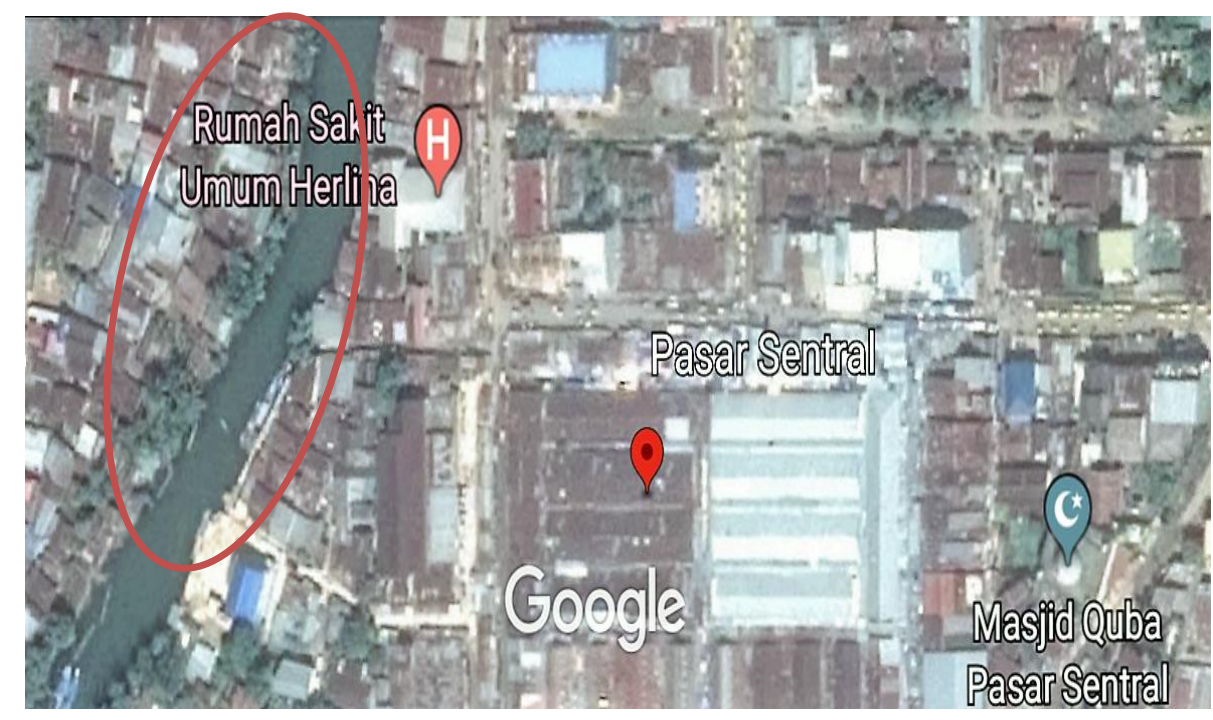

Gambar Lokasi Studi 
Tahapan penyusunan artikel:

1. Menentukan tema

2. Pengambilan data di lokasi study

3. Analisa data

4. Membuat kesimpulan untuk menjawab tujuan penulisan artikel.

Semua metode penulisan dan analisa dalam artikel ilmiah ini merujuk pada panduan penulisan tugas akhir Fakultas Teknik Universitas Muhammadiyah Sorong tahun 2014 (Pristianto , Amri \& Rusdi, 2018 ).

\section{HASIL DAN PEMBAHASAN}

Penelitian dengan tema yang sama.

Beberapa hasil penelitian dari lima rumah yang saya teliti terkait tema artikel ini adalah sebagai berikut :

1. Kondisi jalan yang ada cukup memenuhi karena jalan utamanya lumayan lebar dan kondisi jalan sudah jalan beton, hanya jalannya sudah mengalami kerusakan ringan.

2. Kondisi air bersih yang ada kurang memenuhi karena sebagian besar menggunakan air dari PDAM dan air dari PDAM mengalir seminggu 2 kali dengan kualitas yang buruk. Disebabkan karena jaringan-jaringan pipa dari PDAM tidak pernah dibersihkan hingga menyebabkan lumpur-lumpur dari air mengendap dan juga terjadinya penyumbatan. Penyumbatan juga bias terjadi karena rusaknya pipi-pipa dari PDAM. Harga air PDAM perbulan Rp.80.000/bulan. Adapun Sumur galian yang digunakan tapi menggunkan mesin untuk memompa air.

3. Kondisi drainase yang ada kurang memenuhi karena kondisi drainase perumahan terlalu kecil yang membuat air tergenang karena elevasi yang kurang tepat sehingga menjadi sarang nyamuk. Kondisi drainase tersumbat kebanyakan karena tumpukan material yaitu tanah atau pasir serta sampah dan sebagian drainase terputus. Jika tidak ada drainase maka akan terjadi genangan air yang berlebihan.

4. Kondisi persampahan kurang memenuhi karena warga lebih memilih membuang sampah kesungai dikarenakan TPS yang terlalu jauh dari rumah warga dan tidak ada TPS yang disiapkan di tiap-tiap komplek. Kebanyakan rumah yang saya survey membuang sampah disungai, ada juga yang membuang sampah non organic ke TPS dikarenakan sadar akan dampak yang akan terjadi, namun masih membuang sampah organiknya kesungai dan semua kendala hanya karena TPS yang terlalu jauh dari permukiman warga. Dua sampai tiga kali dalam seminggu warga membuang sampah disungai dan juga dua sampai tiga kali dalam seminggusampahdibawake TPS. Sampah di bawah sendiri ke TPS tidak dilakukan oleh petugas dikarenakan tidak ada petugas kebersihan disetiap komplek. Sampah selalu dibawah ke TPA 7 kali dalam seminggu. Kondisi TPS sangat tidak memadai, kontener sampah yang disiapkan tidak cukup dan di kelurahan Remu Selatan, Kecamatan Manoi, RW05/RT01 memiliki jumlah warga yang sangatbanyak dansampah-sampah yang dari pasar juga dibuang 
dikontener tersebut hingga sampah selalu berserakan diluar kontener karena tidak muat dalam kontener.

5. Kondisi air Limbah kurang memenuhi karena limbah rumah tangga di alirkan kesungai dan membuat air sungai tercemar hingga tidak ramah lingkungan. Sumber utama dari air limbah didaerah tersebut adalah air dari kamar mandi dan bekas cuci. Setiap rumah warga menggukana WC pribadi dan sangat layak. Namun jika septik tank sudah penuh kebanyakan mereka membuangnya kesungai.

\section{$\underline{\text { Analisa }}$}

1. Kerusakan jalan, contohnya seperti jalan yang berlubang-lubang

2. Keberadaan air bersih yang sangat sulit didapatkan karena setiap rumah yang di data kebanyakan menggunakan air PDAM, dan kualitas air PDAM sangat buruk.

3. Penyumbatandrainase terjadi karena tertutup oleh material yang jatuh kedalam drainase dan tidak di bersihkan, begitupun dengan sampah-sampah yang menyumbat drainase.

4. Pembuangan sampah yang tidak tepat dilakukan oleh warga sekitar dikarenakan TPS yang tersedia di sekitar permukiman terlalu jauh.

5. Air limbah rumah tangga yang dibuang secara langsung kesungai hingga membuat sungai sangat tercemar.

\section{KESIMPULAN}

Kondisi jalan yang ada cukup memenuhi hanya jalannya sudah mengalami kerusakan ringan. Air bersih yang ada kurang memenuhi karena sebagian besar menggunakan air dari PDAM dan air dari PDAM mengalirseminggu2 kali dengankualitas yang buruk. Drainase yang ada kurang memenuhi karena kondisi drainase perumahan terlalu kecil yang membuat air tergenang karena elevasi yang kurang tepat sehingga menjadi sarang nyamuk dan sebagian drainase terputus. Persampahan kurang memenuhi karena TPS terlalu jauh dari permukiman dan kontener yang disiapkan terlalu sedikit. Air Limbah kurang memenuhi karena limbah rumah tangga di alirkan kesungai dan membuat air sungai tercemar hingga tidak ramah lingkungan.

\section{DAFTAR PUSTAKA}

1. Tugas besar ( Siti Marohatus Hidayatun, 2018)

2. Pristianto, H., Amri, I., \& Rusdi, A. (2018). Pedoman Penulisan Tugas Akhir Fakultas Teknik Universitas Muhammadiyah Sorong. 